УДК 577.1:636.09.616.99:636.5

(C) 2013

Голубцова М. В., здобувач*

Львівський національний університет ветеринарної медицини та біотехнологій імені С. 3. Гжицького

\title{
ДИНАМІКА БІОХІМІЧНИХ ПОКАЗНИКІВ КРОВІ КУРЕЙ ЗА АСОЦІАТИВНИХ ІНВАЗІЙ
}

\section{Рецензент - кандидат біологічних наук Р. І. Хомик}

У прочесі життєдіяльності білки крові курей відіграють важливу фізіологічну роль у складних процесах обміну речовин. Зміни біохімічного складу крові курей за експериментальної інвазії відображають розвиток патологічних та імунних прочесів і свідчать про стресовий стан організму, щуо дає змогу об 'єктивно оцінити вплив різноманітних факторів на організм інвазованих курей. Зміни біохімічних показників крові супроводжувалися гіпопротеїнемією, гіпоальбумінемією, гіперглобулінемією, диспротеїнемією.

Ключові слова: аскаридї, гетеракіси, еймерї, біохімічні показники, білки, альбуміни, глобуліни.

Постановка проблеми. Птахівництво - одне 3 найприбутковіших i найефективніших галузей України. Біологічні особливості курей дають можливість порівняно швидко отримувати м'ясну та яєчну продукцію, що обумовлює їі високу рентабельність та окупність.

Зважаючи на це, нині виникла потреба у вивченні впливу різних патогенних чинників на організм курей. До того ж особлива увага надається гематологічним дослідженням завдяки тому, що кров бере участь у всіх фізіологічних функціях організму. Вивчення змін рівня білка та білкових фракцій у сироватці крові, взаємопов'язаних із продуктивністю курей, має важливе значення [1]. Кров $є$ посередником в усіх процесах обміну речовин і знаходиться у постійному контакті (через тканинну рідину) з усіма органами й тканинами, відображає всі внутрішні процеси, що відбуваються, змінюючись сама як кількісно, так і якісно [2-4].

Аналіз останніх досліджень і публікацій, у яких започатковано розв'язання проблеми. Останніми дослідженнями встановлено, що аскаридіозна інвазія викликала у курей та курчат глибокі вторинні імунодефіцити, збільшення кількості еозинофілів [4]. Загальний білок та білкові фракції крові відіграють важливу роль у різноманітних життєвих процесах. Пояснюється це, головним чином, природою білків, які лежать в основі різноманітних фізіологічних функцій тваринного організму, їх різними специфічними фізико-хімічними та біологічними властивостями й особливою пластичністю $[1,5,6]$. Вони беруть активну участь у побудові ферментних $\mathrm{i}$ гормональних систем організму, а тому будь-які зміни вмісту та співвідношення білків у крові впливають на весь організм $[3,7,8]$.

Мета і завдання досліджень. Метою нашої роботи було вивчення патогенної дії аскаридій, гетеракісів та ендогенних стадій еймерій на біохімічні показники курей. У завдання роботи входило: провести зараження курей яйцями аскаридій, гетеракісів та ооцистами еймерій; визначити вміст загального білка та білкових фракцій у крові курей.

Матеріали і методики досліджень. Для вирішення поставлених завдань проводилося чотири наукових експерименти. Для кожного експерименту було сформовано контрольну і три дослідні групи курей-несучок за принципом аналогів, враховуючи масу тіла та фізіологічний стан. Кожна група складалася 3 восьми курей віком 4 тижні на початок кожного експерименту. Яйця отримували від статевозрілих аскаридій та гетеракісів і культивували до інвазійної стадії за методикою, описаною Г. А. Котєльніковим [9]. Накопичення, споруляцію та визначення інвазійної кількості проводили за методикою Long et al. (1976) 3 деякими модифікаціями [10]. Курей першої дослідної групи заражали в кількості 500 інвазійних яєць аскаридій та гетеракісів на курку, які вводили за допомогою резинового зонду в 2 \% крохмальному гелі з необхідною концентрацією в об'ємі 0,2 мілілітра. Курей другої дослідної групи заражали в кількості 500 яєць аскаридій та суспензією інвазійних ооцист у кількості 50000 на курку. Курей третьої дослідної групи заражали в кількості 500 інвазійних яєць аскаридій та гетеракісів та суспензією інвазійних ооцист у кількості 50000 на курку. Кури четвертої групи (інтактні) виступали контролем.

* Науковий керівник-доктор ветеринарних наук, професор В. В. Стибель 


\section{СТОРІНКА МОЛОДОГО ВЧЕНОГО}

Матеріалом для біохімічних досліджень слугували відібрані проби крові iз vena axilaris на 7-му, 14-ту, 21-шу та 28-му доби після зараження. Відбір проб крові проводили з дотриманням усіх правил асептики та антисептики.

У сироватці крові курей визначали загальний білок - за біуретовою реакцією [11]. Фракційний склад білків - шляхом електрофорезу на пластинках із поліакриламідного гелю і фотометрі на апараті розшифрування фореграм АРФ-1 [12].

Результати досліджень. Аналіз отриманих даних вказує, що кров курей за експерименталь- ної інвазії, згідно з біохімічниими показниками, суттєво відрізняється від крові контрольних курей. Так, аналіз протеїнограми вказує на зниження обміну білка в організмі курей-несучок за рахунок зменшення вмісту загального білка.

У крові дослідної групи статистично достовірними (за $\mathrm{P}<0,05$, та $\mathrm{P}<0,01$ ) були зміни показників вмісту загального білка за подвійної інвазії аскаридіями та еймеріями й потрійної - аскаридії, гетеракіси та еймерії, порівняно $з$ контрольною групою (див. табл.).

Вплив змішаних інвазій на біохімічні показники крові курчат $(M \pm n, n=8)$

\begin{tabular}{|c|c|c|c|c|c|}
\hline \multirow{2}{*}{$\begin{array}{c}\text { Дослідні } \\
\text { групи }\end{array}$} & \multirow{2}{*}{ До зараження } & \multicolumn{4}{|c|}{ Доби дослідження, після зараження дослідних курей } \\
\hline & & 7 & 14 & 21 & 28 \\
\hline \multicolumn{6}{|c|}{ Загальний білок, г\% } \\
\hline $1 \mathrm{~A}+\Gamma$ & $3,0 \pm 0,34$ & $2,9 \pm 0,42$ & $2,8 \pm 0,49$ & $2,6 \pm 0,47$ & $2,4 \pm 0,26$ \\
\hline $2 \mathrm{~A}+\mathrm{E}$ & $3,1 \pm 0,48$ & $2,8 \pm 0,38$ & $2,8 \pm 0,37$ & $2,7 \pm 0,34$ & $2,3 \pm 0,12 *$ \\
\hline $3 \mathrm{~A}+\Gamma+\mathrm{E}$ & $3,1 \pm 0,39$ & $2,6 \pm 0,54$ & $2,4 \pm 0,23 *$ & $2,2 \pm 0,17 * *$ & $2,1 \pm 0,15^{*}$ \\
\hline $4(\mathrm{~K})$ & $3,2 \pm 0,48$ & $3,4 \pm 0,54$ & $3,3 \pm 0,28$ & $3,2 \pm 0,27$ & $3,2 \pm 0,34$ \\
\hline \multicolumn{6}{|c|}{ Альбуміни, \% } \\
\hline $1 \mathrm{~A}+\Gamma$ & $43,1 \pm 3,04$ & $41,2 \pm 3,24$ & $38,3 \pm 3,16$ & $36,4 \pm 3,19$ & $35,9 \pm 4,21$ \\
\hline $2 \mathrm{~A}+\mathrm{E}$ & $41,9 \pm 2,98$ & $40,8 \pm 3,35$ & $37,9 \pm 3,27$ & $36,2 \pm 4,01$ & $35,7 \pm 4,13$ \\
\hline $3 \mathrm{~A}+\Gamma+\mathrm{E}$ & $42,7 \pm 3,34$ & $39,2 \pm 3,18$ & $35,4 \pm 3,19$ & $34,7 \pm 4,15$ & $34,2 \pm 3,07^{*}$ \\
\hline $4(\mathrm{~K})$ & $42,2 \pm 3,41$ & $43,4 \pm 2,84$ & $43,8 \pm 3,43$ & $42,5 \pm 3,26$ & $43,5 \pm 2,92$ \\
\hline \multicolumn{6}{|c|}{ Глобуліни, \% } \\
\hline $1 \mathrm{~A}+\Gamma$ & $56,9 \pm 2,92$ & $58,8 \pm 4,07$ & $61,7 \pm 3,23$ & $63,6 \pm 4,32$ & $64,1 \pm 4,42$ \\
\hline $2 \mathrm{~A}+\mathrm{E}$ & $58,1 \pm 3,44$ & $59,2 \pm 3,51$ & $62,1 \pm 2,97$ & $63,8 \pm 3,41$ & $64,3 \pm 4,12$ \\
\hline $3 \mathrm{~A}+\Gamma+\mathrm{E}$ & $57,3 \pm 3,23$ & $60,8 \pm 3,75$ & $64,6 \pm 3,71$ & $65,3 \pm 3,92$ & $65,8 \pm 2,61 *$ \\
\hline $4(\mathrm{~K})$ & $57,8 \pm 3,41$ & $56,6 \pm 2,84$ & $56,2 \pm 3,43$ & $57,5 \pm 3,26$ & $56,5 \pm 2,92$ \\
\hline \multicolumn{6}{|c|}{ 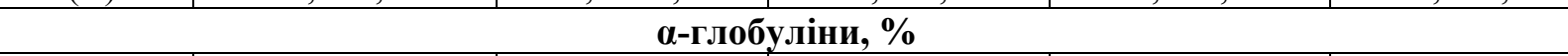 } \\
\hline $1 \mathrm{~A}+\Gamma$ & $20,9 \pm 0,42$ & $18,9 \pm 0,32$ & $20,3 \pm 0,29$ & $20,0 \pm 0,33$ & $19,9 \pm 0,35$ \\
\hline $2 \mathrm{~A}+\mathrm{E}$ & $20,5 \pm 0,68$ & $18,3 \pm 0,27$ & $19,0 \pm 0,31$ & $19,8 \pm 0,36$ & $19,7 \pm 0,27$ \\
\hline $3 \mathrm{~A}+\Gamma+\mathrm{E}$ & $20,8 \pm 0,29$ & $19,1 \pm 0,24$ & $19,5 \pm 0,27$ & $19,9 \pm 0,43$ & $19,6 \pm 0,35^{*}$ \\
\hline $4(\mathrm{~K})$ & $21,8 \pm 0,96$ & $18,6 \pm 0,81$ & $19,6 \pm 0,61$ & $20,9 \pm 0,69$ & $21,0 \pm 0,45$ \\
\hline \multicolumn{6}{|c|}{$\beta$-глобуліни, \% } \\
\hline $1 \mathrm{~A}+\Gamma$ & $15,1 \pm 0,42$ & $16,2 \pm 0,31$ & $16,8 \pm 0,33$ & $17,2 \pm 0,37$ & $17,5 \pm 0,42^{*}$ \\
\hline $2 \mathrm{~A}+\mathrm{E}$ & $15,8 \pm 0,38$ & $16,1 \pm 0,39$ & $17,4 \pm 0,27 * *$ & $17,5 \pm 0,32 *$ & $17,8 \pm 0,33^{* *}$ \\
\hline $3 \mathrm{~A}+\Gamma+\mathrm{E}$ & $16,2 \pm 0,24$ & $16,6 \pm 0,32 *$ & $17,6 \pm 0,29 * *$ & $17,8 \pm 0,27^{* *}$ & $17,8 \pm 0,29 * *$ \\
\hline $4(\mathrm{~K})$ & $16,8 \pm 0,16$ & $15,2 \pm 0,41$ & $16,1 \pm 0,28$ & $16,4 \pm 0,22$ & $15,8 \pm 0,41$ \\
\hline \multicolumn{6}{|c|}{$\gamma$-глобуліни, \% } \\
\hline $1 \mathrm{~A}+\Gamma$ & $20,9 \pm 0,22$ & $23,7 \pm 0,58$ & $24,6 \pm 1,02 * *$ & $26,4 \pm 0,72 * * *$ & $26,7 \pm 0,89 * * *$ \\
\hline $2 \mathrm{~A}+\mathrm{E}$ & $21,8 \pm 0,18$ & $24,8 \pm 0,57 * *$ & $25,7 \pm 0,77 * * *$ & $26,5 \pm 0,94 * * *$ & $26,8 \pm 0,71 * * *$ \\
\hline $3 \mathrm{~A}+\Gamma+\mathrm{E}$ & $20,3 \pm 0,24$ & $25,1 \pm 0,33 * * *$ & $27,5 \pm 0,32 * * *$ & $27,6 \pm 0,89 * * *$ & $28,4 \pm 0,97 * * *$ \\
\hline $4(\mathrm{~K})$ & $19,2 \pm 0,33$ & $22,8 \pm 0,29$ & $20,5 \pm 0,89$ & $20,2 \pm 0,93$ & $19,7 \pm 0,84$ \\
\hline \multicolumn{6}{|c|}{$\mathrm{A} / \boldsymbol{\Gamma}, \%$} \\
\hline $1 \mathrm{~A}+\Gamma$ & 0,76 & 0,70 & 0,62 & 0,57 & 0,56 \\
\hline $2 \mathrm{~A}+\mathrm{E}$ & 0,72 & 0,69 & 0,61 & 0,57 & 0,56 \\
\hline $3 \mathrm{~A}+\Gamma+\mathrm{E}$ & 0,75 & 0,64 & 0,55 & 0,53 & 0,52 \\
\hline $4(\mathrm{~K})$ & 0,73 & 0,77 & 0,78 & 0,74 & 0,77 \\
\hline
\end{tabular}




\section{СТОРІНКА МОЛОДОГО ВЧЕНОГО}

Протягом усіх діб експерименту в крові курей дослідних груп було встановлено тенденцію до зменшення вмісту альбумінів, проте вірогідне зниження встановлено лише за потрійної інвазії на $21,4 \%(\mathrm{P}<0,05)$. Зниження альбумінів у крові пояснюється порушенням синтетичних процесів альбуміну в печінці та вказує на більш інтенсивне використання білків цієї фракції як пластичного матеріалу.

Достовірно зросла в 1,2 разу кількість глобулінів за інвазування аскаридіями, гетеракісами та еймеріями на 28-му добу експерименту, порівняно 3 контролем. Збільшення глобуліну в сироватці крові інвазованих курей відбувалося за рахунок подразнення токсинами паразитів і продуктами розпаду білка системи мононуклеарних фагоцитів. Збільшення глобуліну свідчить про наявність запальних процесів в організмі.

За відношенням $\alpha, \beta$ і $\gamma$-глобулінів до загального білка сироватки крові інвазованих курей можна аналізувати ступінь перебігу захворювань, загострення або згасання інвазіі.

На 28-му добу досліджень встановлено вірогідне підвищення $\alpha$-глобулінів за потрійної інвазії на $6,7 \%(\mathrm{P}<0,05)$ стосовно контролю. Вірогідне зростання $\beta$-глобулінів було встановлено за інвазування аскаридіями на 28-му добу в 1,1 разу $(\mathrm{P}<0,05)$, за інвазії аскаридіями й еймеріями на 14-ту, 21-шу і 28-му добу в $1,1(\mathrm{P}<0,01), 1,2$ $(\mathrm{P}<0,05)$ та $1,1(\mathrm{P}<0,01)$ рази відповідно; за потрійної інвазії на 7-му, 14-ту, 21-шу, 28-му добу - в 1,09 ( $<<0,01), 1,08(\mathrm{P}<0,01)$ та 1,12 $(\mathrm{P}<0,01)$ рази відповідно.

Серед білкових фракцій за асоціативних інвазій найдостовірніші зміни відмічено у $\gamma$-глобулінів, які за імунохімічним відношенням відповідають імуноглобуліну $\mathrm{G}_{1}$. За сучасними даними, імуноглобуліни класу $\mathrm{G}_{1}$ відіграють вирішальне значення в забезпеченні імунного статусу, проте внаслідок гальмування синтезу білка стають особливо вразливими, поскільки вони $є$ швидко відновлювальними білками.

У наших дослідженнях спостерігалося вірогі-

\section{БІБЛІОГРАФІЯ}

1. Аврутина А. А. Использование зффектов гетерозиса при создании яичных кроссов с повышенной адаптационной способностью к клеточной технологии содержания / А. А. Аврутина, И. И. Попов, В. В. Татарчук [и др.] // Инбридинг и гетерозис в животноводстве. - Ленинград, 1984. - C. 88.

2. Аврутина А. Особенности обмена веществ у цыплят в связи со скоростью роста и оплатой дне підвищення $\gamma$-глобулінів за всіх типів змішаних інвазій. У крові курей, які одночасно були уражені яйцями аскаридіями і гетеракісами, відмічено зростання $\gamma$-глобулінів на 14-ту добу - в $1,2(\mathrm{P}<0,01)$, на 21-шу - в 1,3 ( $<<0,001)$, на 28-му - у 1,4 рази $(\mathrm{P}<0,001)$. За інвазування курей аскаридіями та еймеріями зростання $\gamma$-глобулінів статистично відмічали на 7-му, 14-ту, 21-шу, 28му добу, що порівняно з контролем більше, відповідно, в 1,1, 1,3, 1,3, 1,4 рази. За інвазії аскаридіями, гетеракісами та еймеріями встановлено тенденцію до збільшення $\gamma$-глобулінів у наступні дні експерименту: на 7-му добу - в $1,1(\mathrm{P}<0,001)$, 14-ту - в 1,3 ( $<<0,001), 21$-шу - в 1,4 ( $<<0,001)$, 28 -му - в $1,4(\mathrm{P}<0,001)$ рази відповідно до контролю.

Зміни в білкових фракціях між дослідними i контрольною групами курей призвели до різниці A/Г коефіцієнта. За інвазії аскаридіями і гетеракісами коефіцієнт $\mathrm{A} / \Gamma$ протягом усіх днів експерименту був нижчий від контрольних показників у $1,1,1,3,1,3,1,4$ рази відповідно. За інвазії аскаридій + еймерій різниця коефіцієнта $\mathrm{A} / \Gamma$ між контролем і дослідними групами становила 0,08 , $0,17,0,17,0,21$ відповідно до контрольних діб експерименту. За асоціації аскаридій + гетеракісів + еймерій зміни $\mathrm{A} / \Gamma$ коефіцієнта були також зафіксовані протягом усіх діб дослідження.

\section{Висновки:}

1. Зміни білкового обміну служать важливим об'єктивним показником стану організму як у нормі, так і в патології. Склад білку і білкових фракцій характеризують ступінь резистентності організму.

2. За експериментальних інвазій курей відмічали зміни біохімічних показників крові, що супроводжувалися гіпопротеїнемією, гіпоальбумінемією, гіперглобулінемією, диспротеїнемією.

3. У зв'язку з одержаними результатами потребує вивчення впливу преімагінальних стадій аскаридій, гетеракісів та ендогенних стадій еймерій на імунологічні показники крові курей.

корма / А. Аврутина; под ред. А. И. Фомина// Наследственность и изменчивость сельскохозяйственной птицы. - М. : Колос, 1966. - С. 137145.

3. Бландова 3. К. Белки и белковые фракции сиворотки крови кур в связи с возрастом и продуктивностью / 3. К. Бландова // Доклады ТСХА. 1961. - Вып. 69. - С. 227-232.

4. Давыљова Е. Ю. Терапевтическое действие 
некоторых антгельминтиков при аскаридиозе кур и их влияние на иммунный статус и естественный микробиоценоз кишечника птиц: автореф. дис. ... канд. вет. наук: 03.00.19 / Е. Ю. Давыдова. - Саратов, 2005. - 19 с.

5. Дурухян C. A. Возрастные изменения некоторых биохимических показателей у разных пород кур в период постэмбрионального развития: автореф. дис. ... канд. биол. наук: 03093 / С. А. Дурухян. - Ереван, 1971. - 19 с.

6. Ионов П. С. Лабораторные исследования в ветеринарной клинической диагностике / П. С. Ионов, В. Г. Мухин, Н. Р. Семушкин [и др.]; под ред. П. С. Ионова. - М. : Государственное издательство сельскохозяйственной литературы, 1957. 288 c.

7. Котельников Г. А. Гельминтологические исследование животных и окружающей среды. М. : Колос, -1984 . -128 с.

8. Кудрявцев A. A. Исследования крови в ветери- нарной диагностике / А. А. Кудрявцев. - М. : Сельхозлит, 1953. - Ч. 2. - 191 с.

9. Методы ветеринарной клинической диагностики: Справочник / Под ред. проф. И. П. Кондрахина. - М. : Колос С, 2004. - 520 с.

10. Общие и специальные методы исследования крови птиц промышленных кроссов. - Екатеринбург - Санкт-Петербург: Уральская ГСХА, НПП «АВИВАК», 2009. - 85 c.

11. Рыбникова В. П. Изменчивость белков сыворотки крови у мясояичных пород кур в процессе роста и развития и их связь с хозяйственнополезными признаками: сборник научных трудов «Методы селекции в мясном и яичном птицеводстве». - Пушкин, 1969. - Вып. ХІІІ. - 263 с. 12. Long P. L., Joyner P. L., Millard B. J., Norton $C$. C. A guide to laboratory techniques in the study and diagnosis of avian coccidiosis // Fol. Vet. Lat. - 1976. - Vol. 6. - P. 201-207. 